\title{
Substituent Effects on Absorption Spectra of 7-Amino-4-Hydroxynaphthalene-2- Sulfonic Acid Based Dyes
}

\section{IYUN, ORA; EGBE, JO; *KANTIOK, GY}

\author{
Department of Chemistry, Ahmadu Bello University, Zaria, Nigeria \\ *Corresponding Author Email: kantiokgrace@gmail.com
}

\begin{abstract}
The synthesis of dyes derived from coupling 7-amino-4-hydroxynaphthalene-2-sulfonic acid (a diazonium salt) with different coupling agents (phenol, p-nitrophenol, vanillin and salicylic acid) respectively yielded four different dyes namely; Dye A, 4-hydroxy-7-((2-hydroxyphenyl)diazenyl)naphthalene-2-sulfonicAcid, Dye B, 4-hydroxy-7-((2-hydroxy-5nitrophenyl)diazenyl)-4-hydroxynaphthalene-2-sulfonic Acid, Dye C, 7-((2-formyl-5-hydroxy-4-methoxyphenyl)diazenyl)-4hydroxy naphthalene-2-sulfonic Acid and Dye D, 2-hydroxy-6-((5-hydroxy-7-sulfonaphthalene-2-yl)diazenyl)benzoic Acid. The wavelengths of maximum absorption of the dyes were determined in different solvents; water, DMF, ethanol and acetone, their $\lambda \max$ was between $510-600 \mathrm{~nm}$. The synthesized dyes were characterized using IR and their melting points determined. The dyes were applied on wool and silk and the effect of $\mathrm{pH}$, time, temperature on the \%exhaustion for both fabrics was determined. The optimum $\mathrm{pH}$ for absorption of the dyes on both fabrics was $3 \& 5$, optimum time $50,75 \& 90$ minutes and optimum temperature 75 and $90^{\circ} \mathrm{C}$ depending on the dye and type of fabric. The Fastness (wash, rub and light) properties of the dyes were also assessed.
\end{abstract}

DOI: https://dx.doi.org/10.4314/jasem.v24i7.17

Copyright: Copyright (C) 2020 Iyun et al. This is an open access article distributed under the Creative Commons Attribution License (CCL), which permits unrestricted use, distribution, and reproduction in any medium, provided the original work is properly cited.

Dates: Received: 16 May 2020; Revised: 29 June 2020; Accepted: 07 July 2020

Keywords: Diazonium, coupling, exhaustion, fastness,

Dyes are colouring agents used in the manufacture of printing inks, paper, paint, pharmaceuticals and textile industries (Gouthaman et al., 2018). They are coloured compounds which show an affinity towards the substrate to which they are being applied. They are generally applied in an aqueous solution (Hassan, 2016; Agho et al., 2017). Considerable innovation has been witnessed in the field of azo dye chemistry based on heterocyclic systems and studies in the synthesis of such derivatives have been reported. Most of the recent research has focused on structural variations of existing types, for example, variations in substituent, especially on the side chains of the coupling components. Many different heterocyclic diazo components have been studied, especially derivatives of thiazole, imidazole etc. owing to the marked effect of such groups on the absorption spectra of dyes (Bashandy et al., 2016; Wadia and Patel 2008). Acid dyes are water soluble anionic dyes and are typically only applied to fibres with positive charges such as polyamide in an acidic bath. They are not used for cotton colouration owing to their low affinity for the fibre and small molecular size that makes it easy for the dye molecules to move out in water. (Vashi et al., 2014; Jabli et al., 2011). Acid dyes are primary organic acids, usually available to the dyer in the form of salts. They are generally applied to fibre from solutions containing sulphuric, formic or acetic acids. However, majority of them are sodium salts of aromatic sulphonic acids but there are a few containing carboxylic groups. Most acid dyestuffs acquire their acidity from the presence of sulphonic acid groups or nitro groups in the molecule (Musa et al., 2013). Modification of substituents e.g. electron donating or electron withdrawing leads to effects (such as bathochromic and hypochromic) in the absorption spectra of dyes (Jiang et al., 2018).

\section{MATERIALS AND METHODS}

Methods adopted for synthesis and application of dyes were gotten from; Broadbent, 2001; Zollinger, 2003; Horrocks and Anand, 2000; Kozlowski, 2012; Mather and Wardman, 2011; Blackburn, (2005).

\section{Synthesis of Dyes}

General Procedure for Diazotization: $2.0 \mathrm{ml}$ of distilled water was added in a beaker with a drop wise (20 drops) addition of $10 \% \mathrm{H}_{2} \mathrm{SO}_{4}$ (sulphuric acid), with continuous stirring while keeping the temperature constant $\left(0-5^{\circ} \mathrm{C}\right)$ using an ice bath. 7-amino-4hydroxynaphthalene-2-sulfonic acid $(2.39 \mathrm{~g}, 0.01 \mathrm{~mol})$ in powdered form was added with constant stirring to the solution until properly dissolved. Sodium Nitrite $\mathrm{NaNO}_{3}(0.8 \mathrm{~g})$ was added to another beaker and properly dissolved with $1 \mathrm{ml} \mathrm{H}_{2} \mathrm{O}$, this mixture was also kept at constant temperature $\left(0-5^{0} \mathrm{C}\right)$ and then 
finally introduced drop wise to the earlier reaction mixture with constant stirring for about 20 minutes.

General Procedure for Coupling: 0.01mole of the coupling agent (Phenol) was dissolved in $1 \mathrm{ml} \mathrm{1:1}$ acetic acid/water while in an ice bath to maintain constant temperature $\left(0-5^{0} \mathrm{C}\right)$. The previously prepared diazonium salt was then added dropwise to the solution over a period of 20 minutes with vigorous stirring. $1 \mathrm{M}$ of $\mathrm{NaOH}$ was also added dropwise till the solution becomes neutral. Stirring was continued for another 20 minutes and the $\mathrm{pH}$ of the solution measured and the colour noted. $0.5 \mathrm{ml}$ of the reaction mixture was then added to $2 \mathrm{ml}$ of $1 \mathrm{M} \mathrm{NaOH}$ and the colour also noted. $0.5 \mathrm{ml}$ of the reaction mixture was also added to $2 \mathrm{ml}$ of $1 \mathrm{M} \mathrm{HCl}$ and the colour noted. The reaction mixture was changed to the $\mathrm{pH}$ that gives the best colour. The dye mixture was cooled on ice to precipitate. Once the solid had formed, the precipitate was filtered and washed with water. The precipitate was then recrystallized by heating using 1:1 ethanol/water. This procedure was also followed in coupling the other coupling agents (p-nitrophenol, salicylic acid and vanillin) with the diazo component.

Application of the dye to Fabric (silk and wool): $1 \%$ stock solution was prepared and $2 \mathrm{ml}$ solution measured so as to obtain $2 \%$ shade. The dye bath prepared for each dye was varied at different $\mathrm{pH}$ values $(3,5,7,9,12)$, at different time intervals $(10,30,50$ ,70, 90 minutes) and different temperature $\left(20^{\circ}, 45^{\circ}\right.$, $60^{\circ}, 75^{\circ}, 90^{\circ} \mathrm{C}$ ). $1 \mathrm{~g}$ of the fabric was weighed and wet before dyeing at the above conditions. conical flask with a solution of Soda Ash $2 \mathrm{~g} / \mathrm{L}$, Soap $5 \mathrm{~g} / \mathrm{L}$, Liquor Ratio (L.R) 50:1 for 30 minutes at $60 \pm 2^{\circ} \mathrm{C}$. The washed samples were rinsed in cold water and then dried at room temperature. The grey scale was used to assess the change in colour between the washed and unwashed sample.

Fastness to Light Test: The dyed wool and silk samples (about $3 \mathrm{~cm} \times 2 \mathrm{~cm}$ ) was placed under direct sunlight for about 6-8hrs daily. It was left for about 2 weeks and adequate ventilation of the sample during exposure was ensured. As exposure proceeds, the samples under test and the standard dyed material were examined at frequent intervals and the change in color of the sample compared visually with the changes that have occurred in the standard. The exposure of the test samples was terminated after about $80 \mathrm{hrs}$ of exposure was ascertained and change in color was examined using the grey scale.

Fastness to Rubbing: Dry rub fastness method was used here. A White felt $(1 \mathrm{cmx} 1 \mathrm{~cm})$ was put into the grove of the rubbing hand and staged. The dyed sample fastened on the tester and run automatically for 1000 counts and then rubbing fastness of the sample cloth and degree of staining is accessed by measuring the stained fret using the grey scale.

\section{RESULTS AND METHODS}

Four azo acid dyes were synthesized by coupling with a diazo component (J-acid) and four different coupling agents. The structures and physical characteristics of the dyes obtained are shown in Table 1

Fastness to Washing Test: ISO wash test NO.3 was used. The prepared dyed sample was placed in a
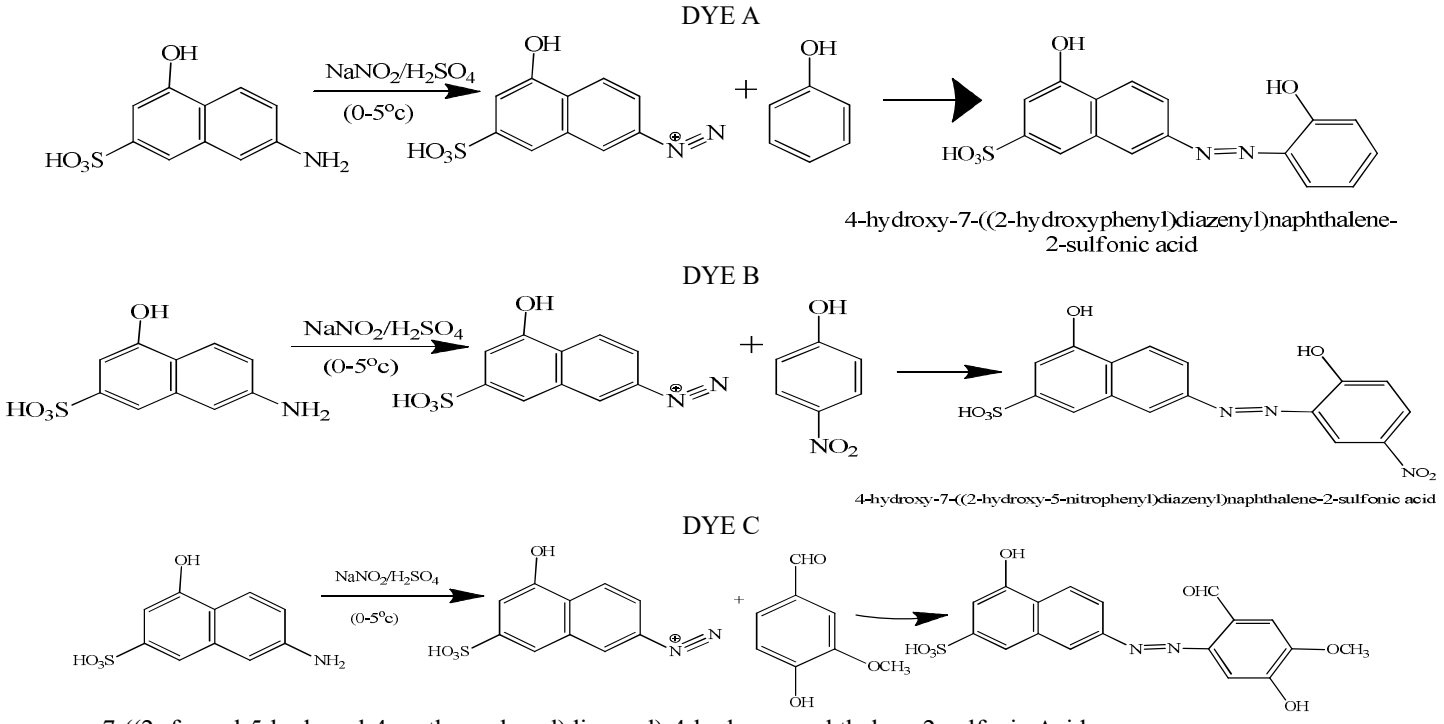

7-((2- formyl-5-hydroxyl-4-methoxyphenyl)diazenyl)-4-hydroxy naphthalene-2-sulfonic Acid

IYUN, ORA; EGBE, JO; KANTIOK, GY 
DYE D<smiles>CC(C)Oc1cc(O)c2ccc(N=Nc3ccccc3C(=O)O)cc2c1</smiles>

SCHEME 1

Table1: Physical Characteristics of the Synthesized Dyes and Structures

\begin{tabular}{|c|c|c|c|c|c|c|c|}
\hline & Name and Structure & $\begin{array}{l}\text { Color of dye } \\
\text { crystals }\end{array}$ & $\begin{array}{l}\text { Melting } \\
\text { point }\left({ }^{\circ} \mathrm{C}\right)\end{array}$ & $\%$ yield & Rf Valve & $\begin{array}{l}\text { Molecular } \\
\text { Weight }\end{array}$ & IR peaks \\
\hline Dye A & $\begin{array}{l}\text { 4-hydroxy-7-((2- hydroxyphenyl) } \\
\text { diazeny1) naphthalene-2-sslfonic } \\
\text { Acid } \quad \text { oH }\end{array}$ & Black & $44-45$ & 62.43 & 0.575 & 344 & $\begin{array}{l}\text { OH- } 3200-3400 \mathrm{~cm}^{-1} \\
\mathrm{~N}=\mathrm{N}-1580.4 \mathrm{~cm}^{-1} \\
\text { Disubs tituted aromatic } \\
\text { ring }-680-810 \mathrm{~cm}^{-1}\end{array}$ \\
\hline Dye $B$ & $\begin{array}{l}\text { 4-hydroxy-7-((2- hydroxy1-5- } \\
\text { nitropheny1) diazeny1) naphthalene-2- } \\
\text { sulfonic Acid }\end{array}$ & Dark brown & 114 & 79.84 & 0.625 & 389 & $\begin{array}{l}\text { OH-3369 } \mathrm{cm}^{-1} \\
\mathrm{~N}=\mathrm{N}-1476 \mathrm{~cm}^{-1} \\
\mathrm{NO}_{2}-1300-1390 \mathrm{~cm}^{-1} \\
\text { Para disubstituted } \\
\text { aromatic ring- } 790- \\
840 \mathrm{~cm}^{-1}\end{array}$ \\
\hline Dye C & $\begin{array}{l}\text { 4-hydroxy-7-((2- } \\
\text { nitrophenyl) diazeny1) naphthalene-2- } \\
\text { sulfonic } \\
\text { Acid }\end{array}$ & Dark brown & $84-86$ & 67.73 & 0.666 & 81.07 & $\begin{array}{l}\mathrm{OH}-3339 \mathrm{~cm}^{-1} \\
\mathrm{~N}=\mathrm{N}-1576 \mathrm{~cm}^{-1} \text { sharp } \\
\text { medium } \\
\mathrm{CHO}-2700-2760 \mathrm{~cm}^{-1} \\
\mathrm{OCH}_{3}-1200-1300 \mathrm{~cm}^{-1}\end{array}$ \\
\hline Dye D & $\begin{array}{l}\text { 4-hydroxy-7-((2-rid } \\
\text { nitropheny1) diazenyl) naphthalene-2- } \\
\text { sulfonic } \\
\text { Acid }\end{array}$ & Dark brown & 157 & 81.07 & 0.711 & 388 & $\begin{array}{l}\text { Alcohol OH- } 3235 \mathrm{~cm}^{-1} \\
\text { COOH- } 3343 \mathrm{~cm}^{-1} \\
\mathrm{~N}=\mathrm{N}-1576.7 \mathrm{~cm}^{-1} \text { sharp } \\
\text { medium } \\
\text { Ortho disubstituted } \\
\text { aromatic- } 735-770 \mathrm{~cm}^{-1}\end{array}$ \\
\hline
\end{tabular}

Table2: Solubility and Color of the synthesized dyes in different Solvents

\begin{tabular}{|c|c|c|c|c|c|c|c|c|}
\hline $\begin{array}{l}\text { Solvent } \\
\text { / Dye } \\
\text { Dye A }\end{array}$ & $\begin{array}{l}\text { Water } \\
\text { Solvble } \\
\text { Fuscia pink }\end{array}$ & $\begin{array}{l}\text { Methanol } \\
\text { Partially } \\
\text { Solvble } \\
\text { pink }\end{array}$ & $\begin{array}{l}\text { Ethanol } \\
\text { Partially } \\
\text { solvble } \\
\text { Faint pink }\end{array}$ & $\begin{array}{l}\text { N-hexane } \\
\text { insoluble }\end{array}$ & $\begin{array}{l}\text { Chloroform } \\
\text { insolvble }\end{array}$ & $\begin{array}{l}\text { Ethyl } \\
\text { acetate } \\
\text { Insolvble }\end{array}$ & $\begin{array}{l}\text { DMF } \\
\text { Solvble } \\
\text { pink }\end{array}$ & $\begin{array}{l}\text { Acetone } \\
\text { Partially } \\
\text { Soluble } \\
\text { Light pink }\end{array}$ \\
\hline Dye B & $\begin{array}{l}\text { Solvble } \\
\text { Blue black }\end{array}$ & Insolvble & $\begin{array}{l}\text { Partially } \\
\text { S olvble } \\
\text { Navy blue }\end{array}$ & Ins olvble & Dispersed & insolvble & $\begin{array}{l}\text { Solvble } \\
\text { Blue } \\
\text { black }\end{array}$ & $\begin{array}{l}\text { Partially } \\
\text { Solvble } \\
\text { Blue black }\end{array}$ \\
\hline Dye C & $\begin{array}{l}\text { Solvble } \\
\text { greenish } \\
\text { blue }\end{array}$ & ins olvble & $\begin{array}{l}\text { Partially } \\
\text { Solvble } \\
\text { Navyblue }\end{array}$ & insoluble & Dispersed & insoluble & $\begin{array}{l}\text { Solvble } \\
\text { Navy } \\
\text { blue }\end{array}$ & $\begin{array}{l}\text { Solvble } \\
\text { Navy blue }\end{array}$ \\
\hline Dye D & $\begin{array}{l}\text { Solvble } \\
\text { magenta }\end{array}$ & $\begin{array}{l}\text { Partially } \\
\text { soluble } \\
\text { pink }\end{array}$ & $\begin{array}{l}\text { Partially } \\
\text { S olvble } \\
\text { pink }\end{array}$ & insoluble & Dispersed & Dispersed & $\begin{array}{l}\text { Solvble } \\
\text { magenta }\end{array}$ & $\begin{array}{l}\text { Solvble } \\
\text { Pink }\end{array}$ \\
\hline
\end{tabular}

Table3: Spectroscopic Properties of the synthesized dyes

\begin{tabular}{|c|c|c|c|c|c|c|c|}
\hline \multirow[t]{2}{*}{ Dye No } & \multicolumn{4}{|c|}{ Maxamum absomption Waveleng th $\lambda \max (\mathrm{nm})$} & \multirow{2}{*}{$\begin{array}{l}\text { Conc }(\%) \\
\text { In water }\end{array}$} & \multirow{2}{*}{$\begin{array}{l}\text { Absorbance } \\
\text { in water }\end{array}$} & \multirow{2}{*}{$\begin{array}{l}\text { Extinction } \\
\text { Coefficient } \varepsilon(\text { liter } / \mathrm{mol} / \mathrm{cm})\end{array}$} \\
\hline & Water & DMF & Ethanol & Acetone & & & \\
\hline Lye $A$ & $j+1$ & 200 & $j+0$ & 210 & $1 . \mathrm{w}$ & $2.0+2$ & $2.0+2$ \\
\hline Dye B & 576 & 600 & 562 & 566 & 1.00 & 7.9961 & 7.9961 \\
\hline Dye C & 583 & 590 & 534 & 542 & 1.00 & 7.9185 & 7.9185 \\
\hline Dye D & 539 & 549 & 546 & 520 & 1.00 & 4.4208 & 4.4208 \\
\hline
\end{tabular}




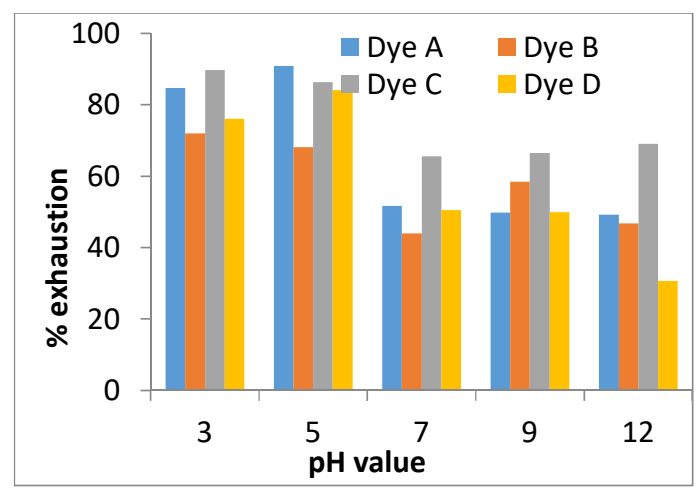

Fig 1 Effect of $\mathrm{pH}$ on dye absorption of silk

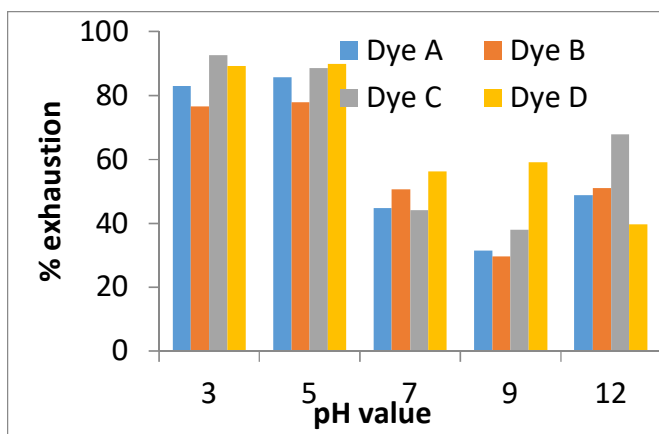

Fig 2. Effect of $\mathrm{pH}$ on dye absorption of wool

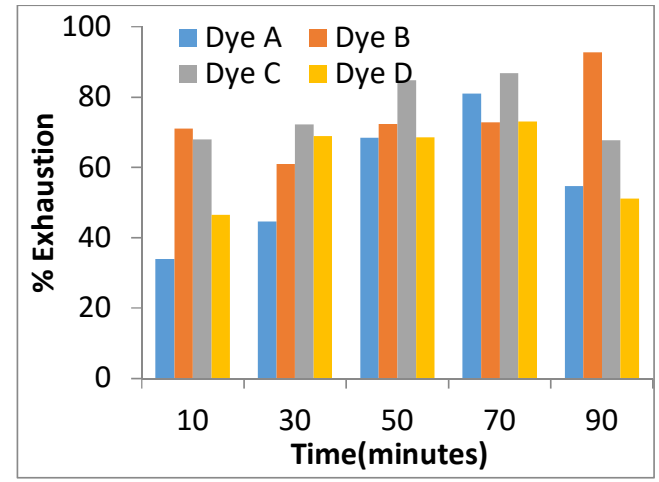

Fig 3. Effect of Time on dye absorption of Silk

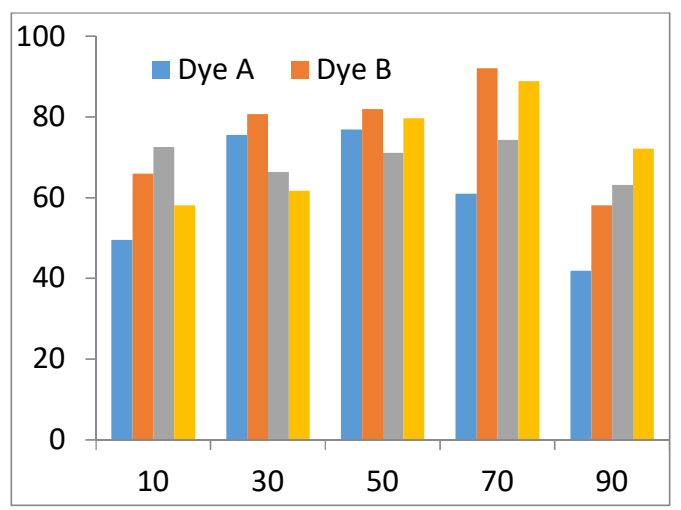

Fig 4. Effect of Time on dye absorption of wool

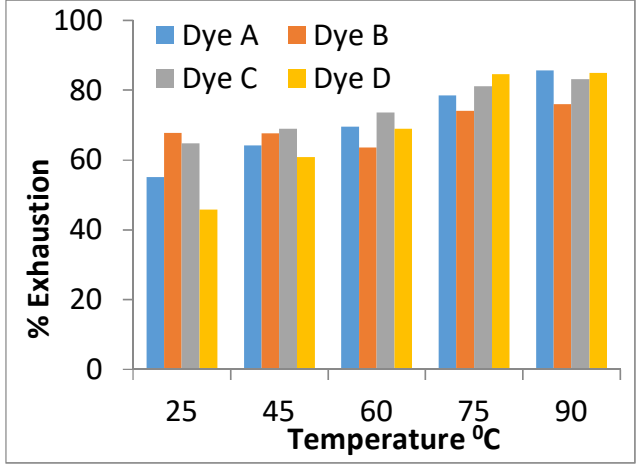

Fig 5. Effect of temperature on dye absorption of silk

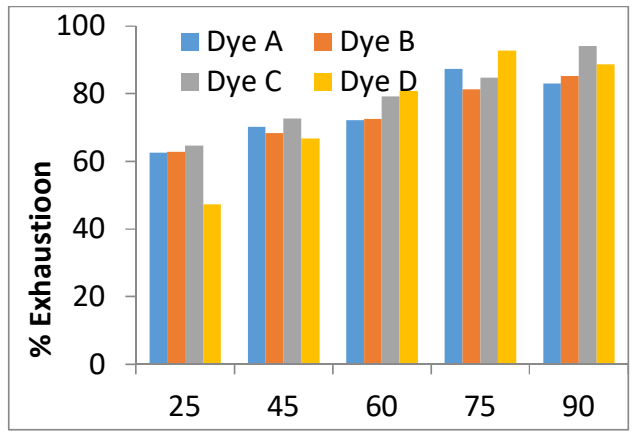

Fig 6. Effect of temperature on dye absorption of wool

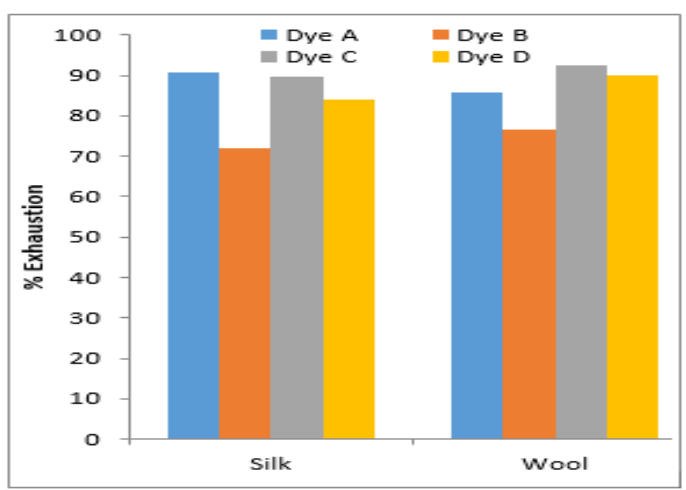

Fig 7. Effect of Type of Fabric (Silk \& wool) on dye Absorption at Optimum $\mathrm{pH}$

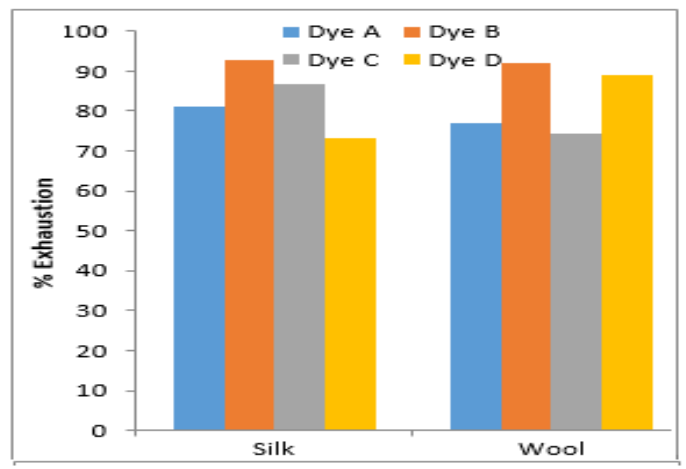

Fig 8. Effect of Type of fabric (silk \& wool) on dye absorption at optimum time

IYUN, ORA; EGBE, JO; KANTIOK, GY 


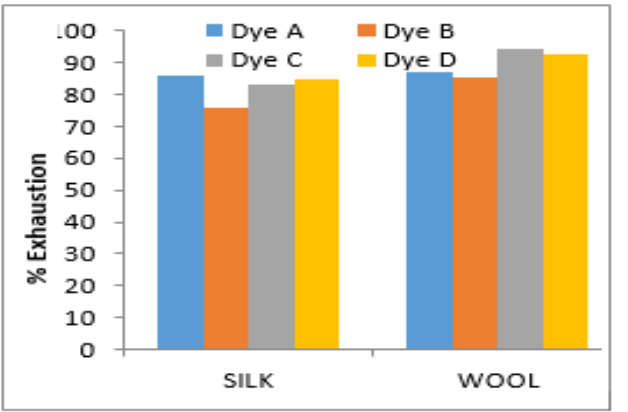

Fig 9. Effect of Type of fabric (silk \& wool) on dye absorption at optimum temperature
Shades of the Dyes: The dyes produced had crystals of different colours as shown in table 1 and in solution they had different colours and shades as shown in table 2 , which resulted from both the nature and position of the substituents in the coupling components. The solubility of the dyes differed in different solvents but as shown all the dyes were soluble in water, which further proofs them as acid dyes. Dye A \& D all gave different shades of pink in different solvents whilst dyes B \& C gave different shades of blue in different solvents.

Table4: Wash Fastness rating on Silk

\begin{tabular}{|c|c|c|c|c|c|c|c|c|c|c|c|c|c|c|}
\hline \multirow[t]{3}{*}{ Dye No } & \multirow{2}{*}{\multicolumn{2}{|c|}{ Optimum pH }} & \multirow{2}{*}{\multicolumn{2}{|c|}{$\begin{array}{l}\text { Time } \\
\text { (70 min.) }\end{array}$}} & \multicolumn{10}{|c|}{ Temperature $\left({ }^{\circ} \mathrm{C}\right)$} \\
\hline & & & & & \multirow{2}{*}{$\begin{array}{r}25 \\
\text { Cs }\end{array}$} & \multirow[b]{2}{*}{$\mathrm{Sc}$} & \multirow{2}{*}{$\begin{array}{l}45 \\
\mathrm{Cs} \\
\end{array}$} & \multirow[b]{2}{*}{$\mathrm{Sc}$} & \multirow{2}{*}{$\begin{array}{l}60 \\
\text { Cs }\end{array}$} & \multirow[b]{2}{*}{$\mathrm{Sc}$} & \multirow{2}{*}{$\begin{array}{l}75 \\
\text { Cs }\end{array}$} & \multirow[b]{2}{*}{$\mathrm{Sc}$} & \multirow{2}{*}{$\begin{array}{l}90 \\
\text { Cs }\end{array}$} & \multirow[b]{2}{*}{$\mathrm{Sc}$} \\
\hline & Cs & $\mathrm{Sc}$ & Cs & $\mathrm{Sc}$ & & & & & & & & & & \\
\hline Dye A & 1 & 1 & 1 & 1 & 1 & 1 & 1 & 1 & 1 & 1 & 1 & 2 & 2 & 1 \\
\hline Dye $B$ & 2 & 2 & 2 & 1 & 2 & 1 & 3 & 1 & 3 & 2 & 2 & 1 & 1 & 1 \\
\hline Dye $\mathrm{C}$ & 2 & 1 & 2 & 2 & 2 & 1 & 1 & 1 & 2 & 1 & 3 & 2 & 2 & 1 \\
\hline Dye D & 2 & 1 & 1 & 1 & 2 & 1 & 2 & 1 & 1 & 1 & 2 & 1 & 3 & 1 \\
\hline
\end{tabular}

Where $1=$ Minimum $5=$ Maximum; Cs- Change of shade of dyed fabric, Sc - Staining of silk cloth

Table 5: Wash Fastness rating on Wool

\begin{tabular}{|c|c|c|c|c|c|c|c|c|c|c|c|c|c|c|}
\hline \multirow[t]{3}{*}{ Dye No } & \multirow{2}{*}{\multicolumn{2}{|c|}{ Optimum $\mathrm{pH}$}} & \multirow{2}{*}{\multicolumn{2}{|c|}{$\begin{array}{l}\text { Time } \\
\text { minutes) }\end{array}$}} & \multicolumn{10}{|c|}{ Temperature $\left({ }^{0} \mathrm{C}\right)$} \\
\hline & & & & & \multicolumn{2}{|l|}{25} & \multicolumn{2}{|l|}{45} & \multicolumn{2}{|l|}{60} & \multicolumn{2}{|l|}{75} & \multicolumn{2}{|l|}{90} \\
\hline & $\mathrm{Cs}$ & $\mathrm{Sc}$ & $\mathrm{Cs}$ & $\mathrm{Sc}$ & $\mathrm{Cs}$ & $\mathrm{Sc}$ & $\mathrm{Cs}$ & $\mathrm{Sc}$ & $\mathrm{Cs}$ & $\mathrm{Sc}$ & $\mathrm{Cs}$ & $\mathrm{Sc}$ & $\mathrm{Cs}$ & $\mathrm{Sc}$ \\
\hline Dye A & 2 & 1 & 2 & 1 & 1 & 1 & 1 & 1 & 1 & 1 & 1 & 1 & 4 & 1 \\
\hline Dye B & 2 & 1 & 3 & 1 & 1 & 1 & 1 & 1 & 1 & 1 & 2 & 2 & 2 & 1 \\
\hline Dye C & 2 & 2 & 2 & 2 & 1 & 1 & 1 & 1 & 3 & 1 & 3 & 1 & 1 & 1 \\
\hline Dye D & 2 & 1 & 2 & 2 & 1 & 1 & 1 & 1 & 1 & 1 & 1 & 2 & 2 & 1 \\
\hline
\end{tabular}

Table 6: Rub Fastness rating on Silk

\begin{tabular}{|c|c|c|c|c|c|c|c|c|c|c|c|c|c|c|}
\hline \multirow[t]{3}{*}{ Dye No } & \multirow{2}{*}{\multicolumn{2}{|c|}{ Optimum pH }} & \multirow{2}{*}{\multicolumn{2}{|c|}{$\begin{array}{ll}\text { Time } & (70 \\
\text { min. }) & \end{array}$}} & \multicolumn{10}{|c|}{ Temperature $\left({ }^{0} \mathrm{C}\right)$} \\
\hline & & & & & \multicolumn{2}{|c|}{25} & \multicolumn{2}{|l|}{45} & \multicolumn{2}{|l|}{60} & \multicolumn{2}{|l|}{75} & \multicolumn{2}{|l|}{90} \\
\hline & Cs & $\mathrm{Sc}$ & Cs & $\mathrm{Sc}$ & $\mathrm{Cs}$ & $\mathrm{Sc}$ & $\mathrm{Cs}$ & $\mathrm{Sc}$ & Cs & $\mathrm{Sc}$ & Cs & $\mathrm{Sc}$ & Cs & $\mathrm{Sc}$ \\
\hline Dye A & 4 & 4 & 4 & 4 & 5 & 4 & 4 & 4 & 5 & 4 & 4 & 4 & 4 & 4 \\
\hline Dye B & 4 & 3 & 4 & 4 & 5 & 5 & 5 & 5 & 5 & 4 & 5 & 4 & 5 & 4 \\
\hline Dye C & 4 & 4 & 4 & 4 & 4 & 4 & 4 & 4 & 4 & 4 & 4 & 4 & 4 & 4 \\
\hline Dye D & 4 & 4 & 4 & 4 & 4 & 3 & 4 & 4 & 4 & 4 & 4 & 4 & 4 & 4 \\
\hline
\end{tabular}

Table7: Rub Fastness rating on Wool

\begin{tabular}{|c|c|c|c|c|c|c|c|c|c|c|c|c|c|c|}
\hline \multirow[t]{3}{*}{ Dye No } & \multirow{2}{*}{\multicolumn{2}{|c|}{ Optimum pH }} & \multirow{2}{*}{\multicolumn{2}{|c|}{$\begin{array}{l}\text { Time } \\
\text { min. })\end{array}$}} & \multicolumn{10}{|c|}{ Temperature $\left({ }^{0} \mathrm{C}\right)$} \\
\hline & & & & & \multicolumn{2}{|l|}{25} & \multicolumn{2}{|l|}{45} & \multicolumn{2}{|l|}{60} & \multicolumn{2}{|l|}{75} & \multicolumn{2}{|l|}{90} \\
\hline & Cs & $\mathrm{Sc}$ & Cs & $\mathrm{Sc}$ & Cs & Sc & $\mathrm{Cs}$ & $\mathrm{Sc}$ & Cs & $\mathrm{Sc}$ & $\mathrm{Cs}$ & $\mathrm{Sc}$ & Cs & $\mathrm{Sc}$ \\
\hline Dye A & 4 & 3 & 4 & 3 & 4 & 3 & 4 & 4 & 3 & 3 & 3 & 3 & 4 & 4 \\
\hline Dye B & 4 & 4 & 4 & 4 & 4 & 2 & 3 & 3 & 3 & 3 & 3 & 3 & 4 & 4 \\
\hline Dye C & 3 & 3 & 4 & 3 & 4 & 4 & 3 & 3 & 3 & 3 & 3 & 3 & 3 & 3 \\
\hline Dye D & 4 & 4 & 3 & 3 & 5 & 3 & 4 & 3 & 4 & 3 & 3 & 3 & 3 & 3 \\
\hline
\end{tabular}

Table8: Light Fastness rating on Silk and Wool

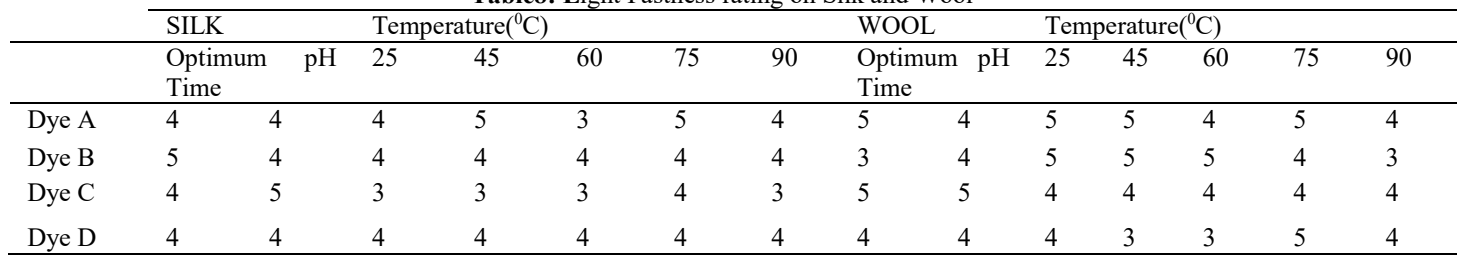


Substituent effects on Absorption Spectra: Substituents attached to a chromophore (the part of the molecule responsible for color) most times have a role to play in the change of spectral band position in the absorption of Electromagnetic Radiation by the dye molecule. These substituents are known as auxochromes. All dyes contain at least one chromophore i.e. a structure with alternating double and single bonds (Broadbent, 2001; Zollinger, 2003; Mather and Wardman, 2011). The four dyes synthesized in this research project share the same chromophores but have different auxochromes hence the difference in color and wavelength. Dye A has the presence of three major auxochromes (two $\mathrm{OH}$ groups and one $\mathrm{SO}_{3}$ group) with a wavelength of $541 \mathrm{~nm}$ and a pink color in solution but Dye $\mathrm{B}$ has an additional auxochrome $\mathrm{NO}_{2}$ which is an electron accepting group, caused a bathochromic shift which increased its wavelength to $576 \mathrm{~nm}$ and hence enhancing its colour to blue black in aqueous solution. Whereas Dye $\mathrm{C}$ has addition of two major auxochromes $\left(\mathrm{OCH}_{3}, \mathrm{CHO}\right)$ which are both electron accepting groups. This caused Dye $\mathrm{C}$ to have the longest wavelength $(583 \mathrm{~nm})$ in water and the deepest color (greenish blue). Dye D had only the addition of a $\mathrm{COOH}$ group which is electron donating hence causing a hypsochromic shift and the shortest wavelength $(539 \mathrm{~nm})$ in water.

Percentage Absorption: Figures 1-9 shows the percentage absorption of the dye by silk and wool fabrics, the wool showed mostly a higher percentage of uptake compared to the silk and this can be attributed to the structure of the fabric being dyed. Silk is more crystalline than wool hence the particles involved in the crystal of silk are more tightly packed thereby limiting the influx of the dye molecules within its packed space but wool on the other hand is not so crystalline which denotes that its structure is less packed and therefore the dye molecules can move more freely through it, enhancing its dye uptake (Kozlowski, 2012). Silk possesses only one site for easy attachment of the dye i.e. the -NH site, for bonding to occur on the right site, the silk has to be treated first which was not carried out primarily in the application process of this project work, whereas, wool contains double sites for attachment on the right and left. Although polymeric materials like silk and wool use up their lone pairs and site of attraction to form the polymeric bonds, wool still showed greater absorption.

Wash fastness: The four dyes synthesized in this research project are all acid dyes which are known for their great solubility in aqueous solution, Therefore, wash fastness depends majorly upon the dyes (Zollinger, 2003). Due to the polar nature of water, the ionic bonds between the fabric and the dye will easily dissociate in water hence causing the colour fastness to be poor in aqueous solution. The high solubility of these acid dyes caused a high percentage exhaustion because the dye molecules from the dye bath easily bonded to the fabric due to high polarity but when placed in the wash liquid the dye which had been attached also easily to the fabric can dissociate.<smiles>[R]C(NC(=O)C([R2])NC(=O)C([R1])[Y17]([R])([H])[H])C(C)=O</smiles>

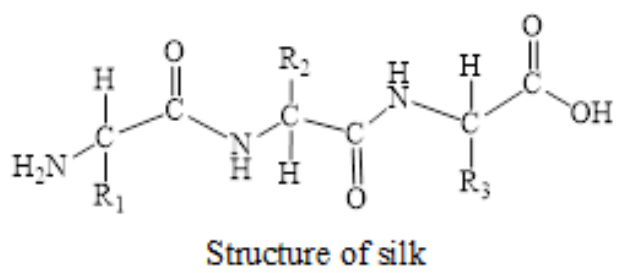

Conclusion: The study showed that a new set of azo acid dyes were synthesized in fairly moderate and good yields with very good to excellent uniform dyeing. The diazo component and nature of the substituents in the coupling components have effects on the visible absorption and the shade of dyeing. Parameters such as $\mathrm{pH}$, time and temperature also have effects on the percentage absorption and fastness properties of said dyes. The synthesized dyes were all soluble in water as this can reduce the cost for purchasing of solvent for dilution, testing and application.

Acknowledgements: Chemistry Department Ahmadu Bello University, Zaria, Polymer and Textile Department Ahmadu Bello University, NILEST Zaria.

\section{REFERENCES}

Agho, OB; Nkeonye, PO; Kogo, AA; Enyeribe, CC; Obadahun, J; Idoko, GO (2017). Synthesis and Application of Heterocyclic Disperse and Acid Dyes Derived from 2- Aminothiophene and Conventional Amines as The Diazo Components. IJARP 1(5); 440-447.

Bashandy, MS; Mohamed, FA; El-Molla, MM; Sheier, MB; Bedair, AH (2016). Synthesis of Novel Acid Dyes with Coumarin Moiety and Their Utilization for Dyeing Wool and Silk Fabrics. Open journal of medicine chemistry, 6: 18-35. 
Blackburn, RS (2005). Biodegradable and Sustainable Fibres. Woodhead Publishing, Cambridge, UK.

Broadbent, AD (2001). Basic Principles of Textile Coloration. Society of Dyers and Colourists, Vol 1 Bradford, UK.

Gouthaman, A; Azarudeen, RS; Gnanaprakasam, A; Sivakumar, VM; Thirumarimurugan, M (2018). Polymeric nanocomposites for the removal of Acid red 52 dye from aqueous solutions: Synthesis, characterization, kinetic and isotherm studies. Ecotoxicology and Environmental Safety 160: 4251

Hassan, AS (2016). Basics in colours, dyes and pigments chemistry: A review. Chemistry International, 2(1): 29-36.

Horrocks, R; Anand, SC (2000). Handbook of Technical Textiles. Woodhead Publishing, Cambridge, UK.

Jabli, M; Baouab, MHV; Roudesli, MS; Bartegi, A (2011). Adsorption of Acid Dyes from Aqueous Solution on a Chitosan-cotton Composite Material Prepared by a New Pad-dry Process. Journal of Engineered Fibres and Fabrics, 6(3). http://www.jeffjournal.org

Jiang, H; Zhang, L; Cai, J; Ren, J; Cui, Z; Chen, W (2018). Quinoidal bithiophene as disperse dye: Substituent effect on dyeing performance. Dyes and Pigments doi: 10.1016/j.dyepig.2018.01.017
Kozlowski, R (2012). Handbook of Natural Fibres: Types, Properties and Factors affecting Breeding and Cultivation, vol 1. Woodhead Publishing, Cambridge, UK

Kozlowski, R (2012). Handbook of Natural Fibres: Processing and Applications, vol 2. Woodhead Publishing, Cambridge, UK.

Mather, RR; Wardman, RH (2011). The Chemistry of Textile Fibres. Royal Society of Chemistry, Cambridge.

Musa, H; Abdulmumini, A; Folashade, MO; Usman, B; Abba, H (2013). Studies on the Dyeing of Wool and Nylon Fabrics with Some Acid Dyes. IOSR$J A C, 5(1)$; 11-17.

Vashi, DM; Vashi, PD; Desai, KR; Kapadiya, KK (2014). Synthesis of various acid dyes from benzthiazole derivative. Arch. Appl. Sci. Res., 6(3).

Wadia, DN; Patel, PM (2008). Synthesis and Application of Acid Dyes Based on 3-(4Aminophenyl)-5-benzylidene-2-substituted phenyl-3, 5-dihydroimidazol-4-one. E-Journal of Chemistry, 5(S1): 987-996

Zollinger, H (2003). Colour Chemistry: Syntheses, Properties and Applications of Organic Dyes and Pigments, 3rd ed. Wiley-VCH Verlag GmbH, Weinheim. 